\title{
Beyond Socio-Materiality and Sense-Making: Planting Symbolic Power and Critical Realism into Strategy-As-Practice Logic
}

\author{
Huifen Wang, Guoliang Luo, Huanping Hong \\ Management School, Jinan University, Guangzhou, China \\ Email: twhf@163.com,sunnyluo2006@126.com,hhp5188@vip.qq.com
}

Received 16 January 2016; accepted 29 March 2016; published 1 April 2016

Copyright (C 2016 by authors and Scientific Research Publishing Inc.

This work is licensed under the Creative Commons Attribution International License (CC BY). http://creativecommons.org/licenses/by/4.0/

(c) (7) Open Access

\section{Abstract}

Strategic practice is inherently a social practice shaped by the immediate social context, but capital power does not have a stronger presence in socio-materiality and sense-making. We argue that Bourdieu's relational mode of thinking mode and Archer's critical realism should be tapped into Strategy-As-Practice (SAP) research. Strategic discourse researchers "have limited understanding of how individuals become strategists, or even how some individuals in organizations come to be perceived as 'strategic' whereas others come to be routinely classified as non-strategic and excluded from studies of strategizing. Thus we have much to learn from paying closer attention to strategic discourse and subjectivity" [1]. This paper describes Bourdieu's practice theory and suggests that by this lens we can better understand strategy as power relation construction through which symbolic capital is translated into symbolic value in a strategy transformation organization. Such shift of power relations is viewed as accepting relational mode of thinking and critical realism in strategic practice. From symbolic power perspective, character status and role prestige are ascribed to strategy. Implementation of strategy is configuration of power relation designed by strategists. By exploring strategy as social inclusion and distinction, we review strategy discourse beyond social-materiality. We also apply symbolic capital of Bourdieu's theory to explain world-making beyond sense-making of strategy. We argue that strategies are not based on conscious calculation but rather results from unconscious dispositions towards a particular way of social recognition and inclusion. Strategic discourse analysis maybe has not initially recognized that strategy discourse is a form of symbolic capital used by strategists who wish to bolster social status.

\section{Keywords}

SAP, Socio-Materiality, Critical Realism, Bourdieu's Practice Theory, Symbolic Power, Discourse, Sense-Making 


\section{Introduction}

The lack of capital base and clear symbolic power analysis may be a reason that strategic artifacts presented in the socio-material writings are phenomenal, and why it is difficult to identify subjective power source which acknowledges power relations in strategic context and material artifacts. Strategy discourse researchers have oscillated between two seemingly incompatible points of view or two apparently irreconcilable perspectives: strategic artifacts' materialism and strategist's subjective power. On the one hand, it can treat strategic artifacts such as strategic tools, frameworks, and number-crunching systems as material elements, and thus leaves out everything that they owe to the fact that they are power objects of world-making, or misrecognition within strategic field. On the other hand, it can reduce strategic discourse to form of fiction [2], episodic myth that strategic agents have it. We need to explore what constitute strategic artifacts in strategizing and how they shape and are shaped by more general social conventions attached to, for example, meetings and workshops. Then the task of strategic discourse needs to study the recursive links between strategy tools for doing strategy work in particular situation and the way that they are perpetuated within language that extends well beyond the situation with which they are initially deployed.

Strategy is significant symbolically because of a particular set of capitals in a particular set of fields. Strategic discourses promote strategist's ideas, interests or power positions to make it highly symbolic. But strategic discourse researchers are ignorant of field force embedded in context. As strategic discourse researchers, "we have largely ignorant special arrangement of strategist interactions, even though analysis of spatial arrangements of strategic in other contexts, such as the arrangement of arbitrage desks on Wall Street trading floors, has been shown to have a critical influence on the way that traders interact and the profitability of trades". It is necessary for strategic discourse research to produce an account of symbolic power embedded in strategic discourses and strategic field.

Treating strategy as symbol can deepen power analysis beyond socio-materiality and sense-making. This paper uses Bourdieu's symbolic power to analysis strategy as structuring structures that mediate practices by connecting individuals and groups to institutionalized power relations. We argue that strategy is symbol, which mediates the effects of social structures to produce various forms of capital construction through strategy design and implementation.

In this paper, we try to transcend the artificial opposition that is thus created between strategic activities and representations based on relational mode of thinking. Our major contribution of what must rightly be called the structuralist revolution consists in having applied critical realism to strategic discourse analysis, and which identifies the real not with substances but with relations [3]. Our research tries to transcend strategic activities and events may provide a solution for the problem of the recursive intertwining of humans and tool in strategic practice and the entwining of the material and the social in world-making by symbolic power.

\section{Using Relation Thinking Mode to Combine Macro-Level and Micro-Level Strategic Practice}

Social practice is considered essential to understand what people really do in organizations and to bridge the micro with the macro levels of strategizing [4]-[7]. Within the Strategy-As-Practice perspective, some seminal works, such as Jarzakbowski [8], Johnson [9], Whittington [4]-[5], mobilize practice in Bourdieu's view. Bourdieu allows us to build in the notion of social control into a discursive framework where the power to name remains an integral element; therefore language is not only a means of communication or expression but a tool of power [3] [10]. Oakes et al. (1998) analyze the struggles to name and legitimate practices through business planning process, and the effects of these struggles on the agents and the field [11]. Oakes et al. also evidenced that through the use of symbolic violence, these practices lead to change the position of the agents and the different forms of capital [11].

However, as asserted by Chia [6], "advocates of practice-based approaches to strategy research may have underestimated the radical implications of the work of practice social theorists such as Bourdieu [10] [12]-[16] who they rely upon to justify this turn to practice” [6]. Authors mainly rely on the characteristics of practice and on the relation between practice and habits to understand how individuals develop their practical capacity to strategizing, but they mainly remain at a descriptive stage. They do not take into account the complete possibilities of the framework, mainly because they neglect the concept of field, which is nevertheless essential to understand the link between individuals and actions. 
The nature of society as an open system makes it impossible to make predictions as can be done in natural science. According to Bourdieu's practice, people are not aware of the factors affecting their behaviour, nor the implicit logic behind that behaviour [3]. One of the Bourdieu's key epistemological critiques of the research process was the inability of study participants to critically reflect upon their behaviour because as humans our "practical logic" - the inherent association between what people do and their location in social space-is limited [3]. Just as Chia and Mackey [17] argued that "to understand strategy emergence we are required to develop a certain research sensitivity to the unspoken, the inarticulate and even the oftentimes unconscious aspects of strategy-making”.

Bourdieu suggested that "the principles embodied in this way are placed beyond the grasp of consciousness and hence cannot be touched by voluntary, deliberate transformation cannot even be made explicit" [3] [18]. Bourdieu provided his concepts which he coined a set of "thinking tools" [19]. In spite of the scrutiny and many attempts to apply Bourdieu's theoretical work [20]-[22], the way in which he saw his "thinking tools" being deployed is often overlooked.

Strategy in its objectivist moment, is a social topology, an analysis of relative positions and of the objective relations between social positions. The "social reality" which Durkheim spoke of is an ensemble of invisible relations. We argue that Bourdieu's reltation thinking mode and Archer's critical realism should be tapped into SAP research.

\section{Planting Relational Mode of Thinking into Strategy Logic Based on Critical Realism}

Even though it is always the case that strategy implementations will change power relations, SAP researchers have not payed more attention to power relations based on critical realism (Figure 1).

Traditional research method and paradigm of power is primarily studied using Foucault's institutionalized power definition. The Foucault-inspired study by Ezzamel and Willmott elucidates how top managers and organizational members use strategy discourse to resist the change imposed on them. From critical realism, this kind of power analysis is based on power events and activities, not deepened into power structure and power mechanism.

Bourdieu's work takes power perspective from power reality in which the point of view of the dominant power structure is imposed behind the power events and activities, which maybe cannot seen from empirical strategic practice. Our mental structures are strictly controlled by preconceived thematics which to a large extent are imposed by a broadly invisible state. The thematics portray a particular non-neutral vision of reality which serves to uphold the interests of the most powerful. Strategic meaning (reinforced by objective structures) is imposed upon individuals, groups and classes in a manner which both obscures power relations and legitimates them.

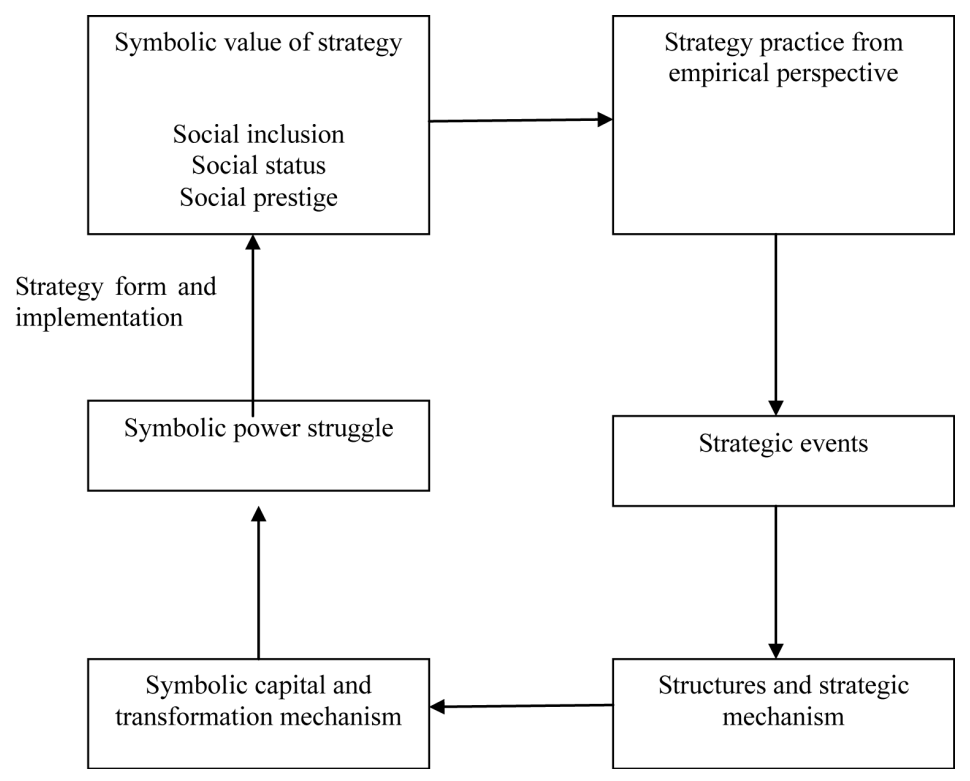

Figure 1. Framework of Strategic field and practice from critical realism. 
Bourdieu described this process as misrecognition, a process, “whereby power relations are perceived not for what they objectively are but in the form which renders them legitimate in the eyes of the beholder” [3]. The imposition of systems of symbolism and meaning which hide objective power relations in a form which renders them legitimate is described by Bourdieu as symbolic violence. Strategic misrecognition means unearths the underlying objective structures of symbolic violence behind strategic events and activities.

To move forward power analysis we need further from "Where and how is the strategic power?" to "Why is strategic power? What is the nature of strategy? Why is strategy?” Practice turn need to combine linguistic turn in philosophy perspective-critical realism.

This research is situated in a critical realist paradigm which, as sociologist Margaret Archer argues, views strategic social practice as "inseparable from its human components because the very existence of society depends in some way upon our activities” [23]. This view is largely consistent with Bourdieu's ontology [10]. “Interactions, which bring immediate gratification to those with empiricist dispositions -they can be observed, recorded, filmed, in sum. They are tangible, one can "reach out and touch them"-mask the structures that are realized in them. This is one of those cases where the visible, that which is immediately given, hides the invisible which determines it. One thus forgets that the truth of any interaction is never entirely to be found within the interaction as it avails itself for observation. One example will suffice to bring out the difference between structure and interaction and, at the same time, between the structuralist vision I defend as a necessary (but not sufficient) moment of research and the so-called interactionist vision in all its forms (and especially ethnomethodology) $[10]$.

Central to critical realism is that the explanation of strategic practice is achieved through revealing the causal mechanisms that produce them [24]. According to critical realism, the objective strategy is reflection of power relations between positions occupied within the distributions of the resources which are or may become active, effective, like aces in a game of cards, in the competition for the appropriation of scarce goods of which this social universe is the site.

By basing this research on the analysis of the causal mechanisms of strategy practice, it is possible to arrive strategic activities at potential consequences of mechanisms that operate in strategy implementation. But, uncovering these causal mechanisms is not a linear process whereby the researcher can ask strategic formers and implementers why they design strategy in a certain way or for what cause. It is important to place symbolic power in strategic field and acknowledge the social space in which symbolic power is embedded.

We argue that Bourdieu's relational mode of thinking and Archer's critical realism should be tapped into SAP research. In this paper we argue that context is relation field which full of power struggle. Individual is social actor who is embedded in social structure. SAP research need to broad reach of strategy design and implementation into a complex set of relationships, classification schemes and social dynamics. Bourdieu discusses in his work on the social field through the concept of symbolic capital and symbolic power. We need to use critical realism to explore power mechanism to SAP research. As part of a critical project, this paper has focused on the power relations in strategy and has tried to express power dominance that entails the privileging of interests over others. We use critical realism and try to explore change of power relations in strategic practice through symbolic power.

\section{Why Is Symbolic Power?}

Agents in strategizing are not only acting and living in the existing social world, but are historically situated and influenced through symbolic power. Bourdieu may serve to help enlighten the power source of critical discourse and struggle nature of linguistic-based strategy. Bourdieu put it, "the 'subject' of what is sometimes called 'company policy' is quite simply the field of the firm or, put it more precisely, the structure of the relation of force between the different agents that belong to the firm” [25]. This emphasizes the force relation of strategists, a struggle for power, a political fight over time between agents.

Symbolic power, which not only serves to make sense of underlying meaning through strategic discourses, but help to form world order and control. Whilst all agents may have the potential to reconstruct reality, that is not to say they are deemed by others as having the legitimacy to do so [10]. It is the dominant, those who have substantial symbolic power and access to resources who are able to access and reproduce mode of thinking in terms of discursive hegemony.

This is especially the strategic discourse analysis with sense-making analysis. On the other hand, the effects 
of and on power relations seem to be highly context dependent. With regard to the functionalist and contextual studies, theoretical reasoning and archival analysis are conducted by Julia Balogun, Clause Jacobs, Eero Vaara and Saku Mantere [1]. Strategy as symbolic capital is nothing other than economic capital, social capital or cultural capital means that symbolic capital is the representation of economic capital, social capital and cultural capital in strategic field. We suggested strategy be symbolic capital to change power relations because symbolic capital is the transformed form of economic capital, social capital and cultural capital. Traditional SAP research are focus on the empirical strategic level and strategic events level which did not deepen into mechanism and structure level as right part of Figure 1.

Critical realism offers researchers tool to explore "black box" of power struggle in strategic practice as top part of Figure 1. The framework discussed symbolic power is a suitable analytical tool for making sense of the maneuverer made by powerful actors to create obligatory passage points for weaker actors. The symbolic value in Figure 1 emphasizes social value aspects such as role status, social inclusion and legitimacy which determine strategic activities. The objective of the paper is to argue that given the complexity of strategic activities, power phenomenon requires a complex and rich theory such as symbolic power. Moreover, the hidden nature of power relationship need to be explored around strategic practice.

As asserted by Chia and MacKay [17], "deliberate intentionality is not a prerequisite for the articulation of a strategy; strategy may emerge as a consequence of the inherent predispositions of an actor to unselfconsciously respond to external circumstances in a manner that we may retrospectively recognize as being consistently strategic" [17]. We should not pay more attention to power shift activities and attributes in strategic forming and implementation, such as discourse style and ritual activities, but think the nature of discourse as symbolic power and cause mechanism of power alteration.

For SAP researchers, we need to further that strategic discourse means social status and prestige. From symbolic power perspective, character status and role prestige is ascribed to strategic discourse.

For SAP researchers, we also need to further that sense-making is not only making clear of strategic vision, but also symbolic dominance through symbolic violence. Beyond sense-making, world-making by symbolic power are invisible mechanism in strategy just as Figure 1 show.

\section{Explore Symbolic Power beyond Socio-Materiality}

Orlikowski's socio-material theory reflects social and material worlds of strategy [26]. Strategic goals, knowledge, government regulations, and the practices of credit rating agencies are entangled with the technological agencies of strategic tool. Routine conversations among strategists and non-strategists trigger intense entanglement and controversies over values, identities, and community within strategic field. But sociomateriality entanglement just reflection of strategic events and activities as in the middle level of Figure 2. We need use critical realism and explore entanglement mechanism and structure in strategic field as showed in the third level of Figure 2.

Beyond socio-materiality, objective relations of power in individual strategists tend to reproduce themselves through the adoption of symbolic power embedded in strategic field. In the symbolic struggle for the production of common sense or, more precisely, for the monopoly over legitimate naming, strategic agents put into action the symbolic capital that they have acquired in previous struggles and which may be rankings guaranteed. Thus titles of nobility, like status of "strategist", strategic vision, educational credentials, represent true titles of symbolic property which give individual a right to share in the profits of recognition. Therefore, symbolic power in strategy is a power of world-making beyond sense-making.

The notion of socio-materiality has recently gained in popularity among organization studies in their search for providing new ways of theorizing about the dynamics between artifacts, practices, and organizations. Influenced by previous literature (in particular Latour [27]; Pickering [28]; Suchman [29]) a number of influential ideas on sociomateriality has been published (see e.g., Leonardi and Barley [30] [31]; Leonardi [32]; Orlikowski [26] [33]-[34]; Orlikowski and Scott [35]). These writings have inspired scholars to offer a sociomaterial view on various topics such as enterprise system implementation [36], mobile IT usage [37], work collaboration in Second Life [34], digital innovation [38]. The imbrication metaphor and digital materiality are particularly useful in the sense that they provide a language that is both clear and recognizable, that is, human and material agencies are distinct phenomena, yet fundamentally interdependent. But the terms that Leonardi uses and the 


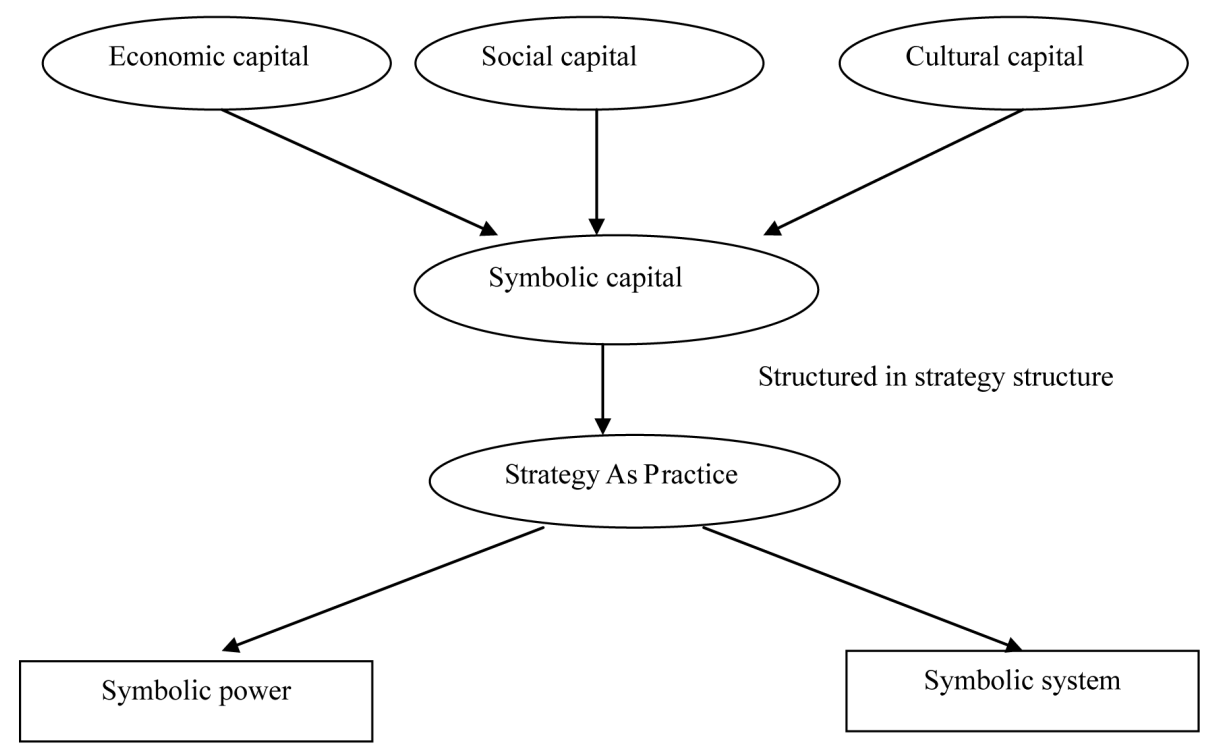

Figure 2. Symbolic power resulted from symbolic capital.

studies he conducts might not explore the power of imbrication. We think that the fundamental cause of imbrication is capital power especially symbolic power.

According to Bourdieu's practice logic, fundamental powers in social relation are economic capital (in its different forms), cultural capital, social capital, and symbolic capital. Symbolic capital is the form that the various species of capital assume when they are perceived and recognized as legitimate [12]. Economic capital "is immediately and directly convertible into money and may be institutionalized in the form of property rights"; cultural capital "may be institutionalized in the form of educational qualifications"; and social capital is an individual feature, which is "the aggregate of the actual or potential resources which are linked to possession of a durable network of more or less institutionalized relationships of mutual acquaintance or recognition”. Thus agents in social are distributed in the overall social space, in the first dimension, according to the overall volume of capital they possess and, in the second dimension, according to the structure of their capital, that is, the relative weight of the different species of capital, economic and cultural, in the total volume of their assets such as economic capital, cultural capital, social capital and symbolic capital.

Symbolic power of strategy is as showed in Bourdieu's power relation [12] gave us another kind of view of strategic power relation. Strategy as a social practice is a symbol which also embedded symbolic capital and symbolic power. Thus strategy designers and implementers are distributed in social space according to the overall volume of capital they possess and adopt different strategic practice. On the other hand, according to the structure of their capital, strategists adopt different strategies based on the relative weight of the different species of capital, such as economic, cultural, social and symbolic capital. Thus power relation change in strategic processes and final value are quite dependent on the total volume of their capital volume and kind. The capital volume and asset species possessed by strategic agents are cause power of change in strategic practice.

According to Bourdieu, symbolic capital can take on forms such as obligations and expectations, information potential, and norms and effective sanctions. Owing to the fact that symbolic capital is nothing other than economic, social or cultural capital when it is known and recognized, when it is known through the categories of perception that it imposes, symbolic relations of power tend to reproduce and to reinforce the power relations that constitute the structure of social space. More concretely, legitimacy of the social world is not, as some believe, the product of a deliberate and purposive action of propaganda or symbolic imposition; it results, rather, from the fact that agents apply to the objective structures of the social world structures of perception and appreciation which are issued out of these which tend to picture very structures and the world as evident. From this point, strategic designers try to world-making structures of social structures of perception and appreciation which tend to picture very structures and the world as evident in strategy.

Therefore, strategy as symbolic capital is nothing other than economic, social or cultural capital when it is adopted and implemented, when it is known through the promotion of strategic promoters that it imposes sym- 
bolic power relations. Strategy designers and implementers tend to reproduce and to reinforce the power relations that constitute structure of social space. More concretely, legitimacy of strategy in worldwide story telling [39] seems the product of a deliberate and purposive action of propaganda or symbolic imposition. In fact, story-telling and strategic ritual is myth making and has symbolic world-making imposition and legitimacy effect underpinning symbolic power relations.

\section{Review Strategic Discourse from Social Recognition Perspective}

The definition of discourse is given as a specific form of language use (spoken or written) and a specific form of social interaction, both understood as a complete communicative event in a social situation. With the evolution of the linguistic turn in critical theory [40], discourse studies have embraced the work of Foucault as a theoretical foundation for strategy research. Laine and Vaara [41] demonstrated the specific role of discourse by dominating and dominated agents. They show that strategic discourses are a space for struggles, "a dialectical battle between competing groups" [41], as Potter suggests, discourse is text and talk in social practices [42].

We can review Strategic discourse from Bourdieu's practice theory with symbolic power. We can use Bourdieu's social practice logic and plant symbolic power into strategy discourse in SAP. Through the act of joining a particular strategy field, agents accept the beliefs and ideologies which co-exist within that arenas and are filtered and transferred back through misrecognition as a mean of understanding themselves and others. Traditional SAP has treated strategy field as a physical place of strategy project, but as social space in Bourdieusian field terms, strategy field is abstract ideology space in itself dynamically driven by symbolic power. Symbolic power embraces dynamic forces within strategy field. Constructions of strategy practice thus smooth over quandaries, struggles and distinction in order to misrecognise inequalities of power [10].

Symbolic power is in some senses more powerful than physical power, in that it is embedded in the very modes of action and structures of cognition of individuals and imposes the vision of the legitimacy of strategy. We argue that strategic symbolism is structured power in the sense that its power is as, if not more, maintain social production and reproduction through strategy.

The Strategy-As-Practice fields, with its focus on strategy as work that individual do have very explicitly sought to recognize the skill and craft involved in strategizing and to explicate some of this skill [1]. The use of social practice logic can be used to shed light on power relations in individual skill and craft in strategy struggle and ploy. This is an objectification technique that Bourdieu recommended researchers use as a process of standing back from the subject to get as close as possible to reaching objective reflection.

When individuals engage in strategic discourse like invisible and symbolic production, they enter a game-like scenario where they draw on their capital to make social gains or "wins". Participation in the "game" of strategy relies on previous accrual and use of capital (e.g. strategic investment, social networking, cultural accumulation, play competency) and knowledge of the rules and engagement in "symbolic struggles" to legitimize social positioning and identities. By adoption a certain strategy such as spatial arrangement, exclusion as non strategist. By inclusion and exclusion in strategic processes express individual affiliation to a social group or rejection of lifestyles or groups to which they do not relate or do not wish to be perceived as related. In this way, strategist are much more complex than they appear at the outset; they are also meaningful, figurative, and an important element of social status and prestige.

"World-making" consists, according to Nelson Goodman [43], "in separating and reuniting, often in the same operation", in carrying out a decomposition, an analysis, and a composition, a synthesis, often by the use of labels. Strategy has become the label of symbolic property of social life worlds. The adoption of a particular strategy in certain boundary means composition and synthesis of knowledge, government regulations, and the practices of credit rating agencies.

Therefore, by discussion of the power dynamics behind strategy implementation assisted researchers to make conscious previously taken-for-granted social ranking and status distinctions. The symbolic property of strategy is also useful to unravel unconscious will from legitimacy.

\section{Review Strategists from Social Distinction and Inclusion}

Strategists construct social distinction in order to build social positions which embedded social power. Social distinction is constructed in such a way that the closer the agents, groups or institutions which are situated within social space, the more common strategy they adopt; and the more distant, the fewer. Therefore, strategy adop- 
tion is not an end in itself, but a means to activating behaviors through which social competencies can be demonstrated and symbolic gains or capital can be achieved according to what is valued by social distinction. Bourdieu's conception of "lifestyle”, that is, a system of classified and classifying practices [8] can be used to analysis strategic style that are embedded in the formation of strategy evolution. To this end, Bourdieu's concept of lifestyle is useful to understand how strategic styles are demarcated and to indicate how different strategic patterns lead to social cohesiveness or dissociation. Strategic style provides a foundation for understanding strategic dynamics or causal processes that highlights how these legitimated styles operate as a form of distinction.

Using Bourdieu's theoretical frame we argue that the sense of strategic fashion regardless of cost, the sense of risk taking regardless enterprise live or die arises from the feeling of acceptance and belonging achieved through emulating social competencies in strategic transformation. Acting in congruence with the norms and mechanism displayed by dominant enterprises, which is verified by more popular peers who have the social authority to know what in vogue and who possesses symbolic capital to dictate, alleviates discomfort in strategic transformation. For example, since 2008, Chinese manufacturing enterprises tried to adopt strategic transformation and update industrial position. Just as one of the famous official slogan say: "If we do not adopt strategic transformation, we are waiting for dying. If we try to adopt strategic transformation, we try to find die. But maybe we can find one way to alive through transformation”.

Find dying legend in Chinese manufacturing transformation seems to be paradox from economical or institutional theory view. But we can find the answer to settle the paradox based on Bourdieu's practice theory. Chinese manufacturing enterprises faced world-wide competition especially from India and Vietnam. Competition for world-making status occurs at two levels: at the multi-field level in which world-wide status is dependent on enterprise type, cost-profit structure, location and reputation; and at the sub-field, in which power struggles take place within industrial sectors. Thus, changing enterprise's social status does not occur by chance. From the outset, the competition is unequal, the stakes and opportunities for accumulation of capital are not evenly distributed. Chinese manufacturing enterprises bring a social history of capital accumulation to each new strategic implementation. Further, social boundaries are imposed by strategic fields. The die sense-making means that it is worse that we do not adopt transformation. But it wouldn't be as bad and maybe find a way to live through transformation.

In attempting to transgress social structures/fields, some of Chinese manufacturing companies ended up subscribing to worldwide dominant norms. For these kind companies, gaining entry to worldwide business mechanism is a source of symbolic capital. Here, strategy is transformed from a sense-making to a socially symbolic and value-laden object capable of communicating social distinctions. Adoption of strategic transformation would renew social history allowing Chinese manufacturing companies a fresh start for world encounter. In reality, the accumulation of capital is intrinsically linked to previous social encounters and therein, opportunities for the accrual of capital. Symbolic capital enables Chinese enterprise entry to worldwide community. Without social networks and symbolic capital, Chinese manufacturing companies would not have opportunity to enter new field and get opportunity of mechanism revolution.

As above official said, strategic transformation conferred upon symbolic capital accrued from subscribing to a way of being that represents the world inclusion and subsequently brings a sense of social ease. This is more of an imperative to Chinese enterprises ever before as all aspects of social life and particularly strategic transformation is becoming increasingly legitimacy. Human cost, environment pressure, forced Chinese enterprises to demonstrate international competence. Transformation is embodied with particular meanings and associations. Enterprises adopt strategic transformation also symbolizes inclusion and legitimacy and build it into part of their identity repertoire. The effects of classification as change and revolution rest on the volume of symbolic capital afforded to enterprises and their subsequent power and authorization to classify. Strategic transformation pattern therefore is based on popular regard, and power in a Bourdieuian sense is the ability to classify successfully, the capacity to make one's definition of the situation as the situation.

\section{Conclusions}

Socio-materiality and sense-making are not enough to explain strategy design and implementation. Bourdieu’s relational mode of thinking and Archer's critical realism provides a base for power analysis for strategic discourse. Researchers have the opportunity to master power relation embedded in strategy by review symbolic power. By doing so, researchers may gain power knowledge based on Bourdiue’s symbolic capital and symbolic 
value.

According to Bourdieu, the principal cause of variations in perception is one's position in social space [13]. By explicating our use of Bourdieu theoretically (his practice) and methodologically (his practice) to understand SAP, we concomitantly offer guidance on the process of conducting theoretically SAP research. Through the outline of a reflexive process of applying social theory to further understandings, some important strategy perspectives come to light surrounding the social and symbolic aspect of SAP.

Sociological thought facilitates more complex understandings of social inclusion and distinction of strategist and non-strategists. We introduce symbolic power of Bourdieu's practice concepts to SAP research. Our work provides Chinese manufacturing enterprise as an example that researchers in strategic transformation can draw on to critical realism and more complete social understandings of symbolic capital underpinning strategy. Strategy means affirming congruence with socially sanctioned practice and aligning internal resources according to what is deemed socially correct or legitimate. Strategy practice highlights acceptable behaviors and creates distinctions between social positions. Bourdieu terms this a "symbolic struggle" over capital [13].

Symbolic power is also ascribed symbolic value transferred symbolic capital. The implications of strategy implementation on power relations cannot only be perceived on strategic processes or function. Power relations depend on how the actors make use of position resulted from symbolic capital. Symbolic power indicates that power has a legitimate source for social position.

Our contribution is exploring symbolic power in strategy and recommends that one must review power from relational mode of thinking and critical realism:

- The content of strategy such as word, template, discourse, ritual, tools, and consultant service is beyond socio-materiality because of symbolic capital which causes power relation change. Symbolic capital is representation of economic capital, social capital and cultural capital.

- Social positions of strategists are recognition and distinction by strategic practice. Strategy transformation is structured and also structuring social position of strategy designers and implementers. Transformation strategy is reflection of social relations, social infrastructure and capital history.

- Social inclusion and recognition are world-making which cause power relation change resulted from symbolic struggle beyond sense-making.

By introducing sociologists Bourdieu to SAP field, we have prepared to ground our explanations in practice theory. We advocate the use of symbolic power theory to arrive at credible research findings and test empirically. Theorizing takes purely descriptive research further so that strategy practice can be examined, compared and understood rather than simply described. We hope to reflect more powerful explanations of social phenomena such as political struggle in strategy design and implementation.

\section{Acknowledgements}

Major Issue with Enterprise Development Research Institute of Jinan University: "Study on Dynamical Mechanism, Strategic Options and Operation Strategy of Enterprise Transformation” 2014ZD002.

\section{References}

[1] Balogun, J., Jacobs, C., Jarzabkowski, P., Mantere, S. and Vaara, E. (2014) Placing Strategy Discourse in Context: Sociomateriality, Sensemaking, and Power. Journal of Management Studies, 22, 175-201. http://dx.doi.org/10.1111/joms.12059

[2] Barry, M.E. (1997) Strategy Retold: Toward a Narrative View of Strategic Discourse. The Academy of Management Review, 22, 429-452.

[3] Bourdieu, P. (1977) Outline of a Theory of Practice. University Press, Cambridge. http://dx.doi.org/10.1017/CBO9780511812507

[4] Whittington, R. (1996) Strategy as Practice, Long Range Planning, 29, 731-735. http://dx.doi.org/10.1016/0024-6301(96)00068-4

[5] Whittington, R., Molloy, E., Mayer, M. and Smit, A. (2006) Practices of Strategising/Organising Broadening Strategy Work and Skill. Long Range Planning, 39, 615-629. http://dx.doi.org/10.1016/j.lrp.2006.10.004

[6] Chia, R. (2004) Strategy-As-Practice: Reflections on the Research Agenda. European Management Review, 1, $29-34$. http://dx.doi.org/10.1057/palgrave.emr.1500012

[7] Jarzabkowski, P., Balogun, J. and Seidl, D. (2007) Strategizing: The Challenges of a Practice Perspective. Human Re- 
lations, 60, 5-27. http://dx.doi.org/10.1177/0018726707075703

[8] Jarzabkowski, P. and Searle, R.H. (2004) Harnessing Diversity and Collective Action in the Top Management Team. Long Range Planning, 37, 399-419. http://dx.doi.org/10.1016/j.lrp.2004.07.007

[9] Johnson, J.L., Lee, R.P-W., Saini, A. and Grohmann, B. (2003) Market-Focused Strategic Flexibility: Conceptual Advances and an Integrative Model. Journal of the Academy of Marketing Science, 31, 74-89. http://dx.doi.org/10.1177/0092070302238603

[10] Bourdieu, P. (1991) Language and Symbolic Power. Polity Press in Association with Basil Blackwell, Cambridge.

[11] Oakes, L.S. (1998) Business Planning as Pedagogy: Language and Control in a Changing Institutional Field—Special Issue: Critical Perspectives on Organizational Control. Administrative Science Quarterly, 43, 257-292.

[12] Bourdieu, P. (1985) The Social Space and the Genesis of Groups. Theory and Society, 14, 723-744. http://dx.doi.org/10.1007/BF00174048

[13] Bourdieu, P. (1989) Social Space and Symbolic Power. Sociological Theory, 7, 14-25. http://dx.doi.org/10.2307/202060

[14] Bourdieu, P. (1990) The Logic of Practice. Polity Press, Cambridge.

[15] Bourdieu, P. (1990) Photography: A Middle-Brow Art. Polity Press, Cambridge.

[16] Bourdieu, P. (1993) The Field of Cultural Production: Essays on Art and Literature. Columbia University Press, New York.

[17] Chia, R. and MacKay, B. (2007) Post-Processual Challenges for the Emerging Strategy-as-Practice Perspective: Discovering Strategy in the Logic of Practice. Human Relations, 60, 217-242. http://dx.doi.org/10.1177/0018726707075291

[18] Bourdieu, P. (1984) Distinction: A Social Critique of the Judgment of Taste. Routledge \& Kegan Paul, London.

[19] Wacquant, L.J.D. (1989) Towards a Reflexive Sociology: A Workshop with Pierre Bourdieu. Sociological Theory, 7, 26-63.

[20] Calhoun, C., LiPuma, E. and Postone, M., Eds. (1993) Bourdieu: Critical Perspectives. University of Chicago Press, Chicago.

[21] Swartz, D.L. (2003) Drawing Inspiration from Bourdieu's Sociology of Symbolic Power. Theory and Society, 32, 519-528. http://dx.doi.org/10.1023/b:ryso.0000005028.96526.75

[22] Swartz, D. and Zolberg, V. (2004) After Bourdieu: Influence, Critique, Elaboration. Kluwer Academic Publishers, Dordrecht.

[23] Archer, M. (1995) Realist Social Theory: The Morphogenetic Approach. Cambridge University Press, Melbourne. http://dx.doi.org/10.1017/CBO9780511557675

[24] Archer, M. (2010) Critical Realism and Relational Sociology: Complementarity and Synergy. Journal of Critical Realism, 9, 199-207. http://dx.doi.org/10.1558/jcr.v9i2.199

[25] Bourdieu, P. (2005) Habitus and Space of Lifestyles. Culture, No. 109-112, 131-170.

[26] Orlikowski, W.J. (2007) Sociomaterial Practices: Exploring Technology at Work. Organization Studies, 28, 14351448. http://dx.doi.org/10.1177/0170840607081138

[27] Latour, B. (2005) Reassembling the Social: An Introduction to Actor-Network-Theory. Oxford University Press, Oxford.

[28] Pickering, A. (1995) It's Not a Property! Exploring the Sociomateriality of Software Usability. Plans and Situated Actions. New York, Cambridge University Press. Sutton, R. I. (2010).

[29] Suchman, L.A. (1987) Understanding Computers and Cognition (Book Review). Artificial Intelligence, 31, $227-232$. http://dx.doi.org/10.1016/0004-3702(87)90024-5

[30] Leonardi, P.M. and Barley, S.R. (2008) Materiality and Change: Challenges to Building Better Theory about Technology and Organizing. Information and Organization, 18, 159-176. http://dx.doi.org/10.1016/j.infoandorg.2008.03.001

[31] Leonardi, P.M. and Barley, S.R. (2010) Sociotechnical Systems Design: Evolving Theory and Practice. In: Bjerknes, G., Ehn, P. and Kyng, M., Eds., Computers and Democracy, Avebury, Brookfield.

[32] Leonardi, P.M. (2011) When Flexible Routines Meet Flexible Technologies: Affordance, Constraint, and the Imbrication of Human and Material Agencies. MIS Quarterly, 35, 147-167.

[33] Orlikowski, W.J. (2006) Material Knowing: The Scaffolding of Human Knowledgeability. European Journal of Information Systems, 15, 460-466. http://dx.doi.org/10.1057/palgrave.ejis.3000639

[34] Orlikowski, W.J. (2009) The Sociomateriality of Organisational Life: Considering Technology in Management Research. Cambridge Journal of Economics, 10, 1-17. 
[35] Orlikowski, W.J. and Scott, S.V. (2008) Sociomateriality: Challenging the Separation of Technology, Work and Organization. The Academy of Management Annals, 2, 433-474. http://dx.doi.org/10.1080/19416520802211644

[36] Scott, S.V. and Wagner, E.L. (2003) Networks, Negotiations, and New Times: The Implementation of Enterprise Resource Planning into an Academic Administration. Information and Organization, 13, 285-313. http://dx.doi.org/10.1016/S1471-7727(03)00012-5

[37] Leclerq, A., Carugati, A., Giangreco, A., Da Cunha, J.V. and Jensen, T.B. (2009) A Sociomaterial View of the Scaffolding of Work Practices with Information Technology. 30th International Conference on Information Systems, Phoenix.

[38] Svahn, F. and Henfridsson, O. (2009) Situated Knowledge in Context-Aware Computing: A Sequential Multimethod Study of In-Car Navigation. International Journal of Advanced Pervasive and Ubiquitous Computing, 1, 23-41. http://dx.doi.org/10.4018/japuc.2009090802

[39] Vaara, E., Sorsa, V. and Pälli, P. (2010) On the Force Potential of Strategy Texts: A Critical Discourse Analysis of a Strategic Plan and Its Power Effects in a City Organization. Organization, 17, 685-702 http://dx.doi.org/10.1177/1350508410367326

[40] Alvesson, M., Karreman, D. and Swan, J. (2002) Departures from Knowledge and/or Management in Knowledge Management. Management Communication Quarterly, 16, 282-291. http://dx.doi.org/10.1177/089331802237242

[41] Laine, P.-M. and Vaara, E. (2007) Struggling over Subjectivity: A Discursive Analysis of Strategic Development in an Engineering Group. Human Relations, 60, 29-58. http://dx.doi.org/10.1177/0018726707075279

[42] Porter, M.E. (1997) Competitive Strategy. Measuring Business Excellence, 1, 12-17. http://dx.doi.org/10.1108/eb025476

[43] Goodman, N. (1978) Ways of Worldmaking. Hackett Publishing Company, Indianapolis. 